\title{
REINSURANCE UTILISATION AND DEPENDENCE ON THE FINANCIAL PERFORMANCE OF NON-LIFE INSURERS: EVIDENCE FROM NIGERIA
}

\author{
Francis S. Dansu \\ Department of Insurance, Lagos State University, Nigeria \\ francisdansu@gmail.com \\ Adebayo M. Obalola \\ Department of Actuarial Science \& Insurance, University of Lagos, Nigeria \\ mobalola@unilag.edu.ng
}

\begin{abstract}
Reinsurance is used by primary insurers as a device to cushion the effect of underwriting and solvency risks. However, an overdependence on reinsurance could cause depletion in the income of the primary insurer. The study examined the effect of reinsurance on the financial performance of non-life insurers in Nigeria. Secondary data used for this research were analysed with descriptive statistics, coefficient of determination $\left(R^{2}\right)$, and linear regression. Results showed a significant positive relationship between reinsurance utilisation and premium growth rate. Similarly, a significant positive relationship was found between reinsurance dependence and profitability (loss ratio). It was recommended that non-life insurers should embrace more of reinsurance facilities particularly for risks of high loss potentials in order to stabilise premium growth rate. In addition, Insurance firms in Nigeria should harness their claims management activities in order to minimise cost and exposure to underwriting risks.
\end{abstract}

Keywords

financial performance; loss ratio; premium growth rate; primary insurers; reinsurance

\section{JEL Classification}

G22

\section{Introduction}

Insurance service providers rely on reinsurance business for financial stability. This is confirmed by studies performed previously in America, Australia, Canada and Pakistan (Iqbal \& Rehman, 2014a; Chen, Hamwi \& Hudson, 2001; Cummins, Dionne, Gagne \& Nouira, 2008; Carneiro \& Sherris, 2005; Tan \& Weng, 2012). While the outcomes of some of these studies highlight the significance of reinsurance to the survival of insurance companies, there seems not to be a universal agreement on the direction of reinsurance contribution to financial performance of ceding companies.

Chen, Hamwi, and Hudson (2001) observed that though reinsurance can be used as a tool to improve the solvency of insurance companies, it could as well increase their insolvency risks. Similarly, Iqbal and Rehman (2014a) noted that reinsurance can significantly contribute to the performance of insurance firms. They further reported that an over dependence on reinsurance can limits an insurer's performance and exposes it to counterparty credit risk. That is, the risk that the reinsurer will fail to honour its side of the contract. It therefore becomes critical that reinsurers remain financially adequate in order to perform their key role to primary insurers.

Reinsurance is defined as the insurance for insurers (Swiss Re, 2004). It could be considered broadly as the transfer of risks from one insurer (Primary Insurer or Cedant) 
to another insurer (the Reinsurer) through an agreement under which the reinsurer agrees, in return for a reinsurance premium to indemnify the cedant for some or all of the financial consequences of certain loss exposures covered by the primary insurer's policy (Iqbal \& Rehman, 2014a). Reinsurance provides quite a number of benefits to the ceding company. According to Cummins et al. (2008) insurers are motivated to seek reinsurance by the same factors that inspire other business organisations to buy insurance.

Specifically, reinsurance reduces volatility of underwriting results of primary insurers, provides them with expertise in key areas of insurance business (product development, pricing, underwriting, and claims management), relieves them of any capital strain, and allows for efficient risk and capital management (Swiss Re, 2004). In addition to these benefits, reinsurance contributes to the growth of the insurance industry and the general development of the economy. (Swiss Re, 2004; Iqbal \& Rehman, 2014b).

Insurance has been found to be highly beneficial to the social, financial, and economic developments of a nation. According to Grant (2012) insurance should be perceived not only as a protection mechanism, but more importantly as a partnership that allows individuals and businesses to spread their wings and go where they might otherwise not have dared to go. As a device that enables risk to be transferred from the insured (the supposed risk bearer) to an insurer (the entity that accept to bear the risk) insurance fosters the economy by accumulating funds from premium and transferring same to deficit economic sectors for financing real investments (Oke, 2012).

The performance of these and other functions of insurance depends highly on the amount of financial security and solvency that accrues to insurance firms through the fundamental roles of reinsurance. Reinsurance contributes in no small measure to the stability of insurance business. Aside from offering technical assistance to ceding companies, reinsurance protects them from capital depletion, stabilises their earnings, and provides capital for alternative uses (Coutts \& Thomas, 1997; Cummins, Dionne, Gagne, \& Nouira, 2008). More precisely, reinsurance aids the management of the underwriting and actuarial risks that primary insurers are exposed to (Swiss Re, 2004; Curak, Utrobicic, \& Kovac, 2014). This according to Veprauskaite and Sherris, (2012) usually reflects in the solvency, earnings and economic value of insurance companies. Given the insight from the literature, this study aims to establish the relationship between the reinsurance practice and financial performance of non-life insurance firms currently operating in Nigeria. Specifically the research aims at observing the effect of the Ratio of Ceded Reinsurance (RCR) and the Ratio of Reinsurance Recoverable to Policyholders' Surplus (RRPHS) on the Premium Growth Rate (PGR) and the Loss Ratio (LR) of the selected firms. The indicators used as independent variables for this present study were selected by Iqbal and Rehman (2014a) and Iqbal and Rehman (2014b) under the Corporate Demand Theory and used for a related study in Pakistan. The study hypothesises that reinsurance utilisation (Ratio of Ceded Reinsurance (RCR)) is not significantly related to profitability (premium growth rate) of Nigerian insurers, and that reinsurance dependence (Reinsurance Recoverable to Policyholders' Surplus (RRPHS)) is negatively related to premium growth rate (Loss Ratio) of Nigerian insurers.

In order to achieve the objective of the study, the rest of this article is organised in this order. The second section contains the review of relevant literatures while the third section discusses the methodology. Data analysis and discussion of findings is contained in the fourth section and section five details the conclusion and recommendations. 


\section{Literature Review}

The usage of reinsurance by primary insurers can significantly improve their performance. This is the outcome of a study conducted by Iqbal and Rehman (2014a) to investigate the impact of reinsurance utilisation on the performance of non-life insurers in Pakistan. With data retrieved from the financial statements of 22 insurance firms in Pakistan, the authors find a positive relationship between reinsurance utilisation and the performance of primary insurers. The results specifically show an existence of reduced loss ratio and expense ratio and an expansion in firm size attributed to the usage of reinsurance. In another study by Iqbal and Rehman (2014b) to examine the relationship between profitability and reinsurance utilisation and dependence by private sector non-life stock insurers of Pakistan. The authors utilise secondary data gathered from 22 insurance companies and conclude that reinsurance utilisation has a significant but positive relationship with the profitability of insurance firms. In addition, the results show that reinsurance dependence and exposure has no effect on insurance companies' profitability.

According to Curak, Utrobicic, and Kovac (2014) the factors influencing the decision of primary insurers operating in developed economies to purchase reinsurance include leverage, size, underwriting results, investment returns, and ownership structure. This raises further questions about the motivating factors that promote the demand for reinsurance in underdeveloped insurance markets. The answer to this fundamental question is provided by the authors through the outcome of a study carried out to investigate firm specific factors that influence the demand for reinsurance by insurance companies in Croatia. They gathered data from 19 insurance companies between 2006 and 2011. The study reveals that leverage, foreign ownership, investment return, and share of non-life insurance positively affect reinsurance purchase. The study however finds a negative relationship between reinsurance demand and size.

In an earlier study carried out by Carneiro and Sherris (2005), econometric test was used to examine factors that determine the demand for reinsurance by Australian insurers; the authors collected a panel data set from the annual reports of 98 Australian insurers for the period from 1996 to 2001. The result of the study reveals an existence of a positive relationship between insurance company's leverage and the demand for reinsurance. The study further finds that the influence of size, taxes, return on investments, and company structure on reinsurance demand are not significant. However, Cummins, Dionne, Gagne, and Nouira (2008) in their study carried out to analyse the costs and benefits of reinsurance to primary insurers suggest that the demand for reinsurance by primary insurers is inspired by the same purposes that encourage individuals and businesses to purchase insurance. Applying data gathered from the U.S. property and Liability insurance firms over a period of nine years (between 1995 and 2003), the authors find that insurers benefits largely from participating in reinsurance activities. They note that reinsurance help limit insurers' insolvency risk by stabilizing loss experience, protecting against catastrophes, increasing underwriting capacity, reducing liability on specific risks, and minimizing rate of claims dispute. In contrast, the study reveals that it is quite expensive to transfer risks to reinsurers. The cost of reinsurance transaction significantly increases an insurer's cost of producing insurance service.

Chen, Hamwi, and Hudson (2001) use data collected from 980 property and liability firms in the U.S. to investigate the effect of ceded reinsurance on solvency of primary insurers. The results of the analysis indicate that usage of reinsurance by primary insurers could trigger the tendency of insurer's insolvency. The study further support this assertion by showing that a less solvent insurer is likely to seek more reinsurance protection because of his perceived difficulty to raise capital in the financial market. 
The performance of United States property and liability reinsurers is measured by Chen and Hamwi (2000). The study focuses on a comparative analysis of the primary insurers and the professional reinsurers using the 1996 data obtained from all the firms operating in the U.S. property and liability sector. Furthermore the study adopts the usage of certain financial ratios to measure the operating performance of the companies. The results indicate that both categories of insurers perform well but at varying respects. Primary insurers generate higher return from underwriting activities compare to investment. Whereas, reinsurers perform better in return on investment than in underwriting profitability.

Primary insurers are constantly confronted by the risk that reinsurers will default in the bid to fulfill their part of the contract. It is this risk that Gatumel and Lemoyne De Forges (2013) examined in their study - understanding and monitoring reinsurance counterparty risk. The authors conclude that monitoring of reinsurers' default risk should not be entirely based on market discipline. They also add that insurance companies must expand their expertise in order to understand their level of exposure to reinsurance counterparty risks. Tan and Weng (2012) conducted a study on enhancing insurer value using Reinsurance and Value-at-Risk criterion. The authors build on the findings of previous researchers to develop a more reliable optimal reinsurance model to be used by primary insurers to achieve better result. The study leads to the development of a model that will assist primary insurers to understand the required measure of risks that should be ceded to reinsurers considering the cost of reinsurance and their motive for profitability.

In a related study, Veprauskaite and Sherris (2012) analyse the reinsurance optimization in life insurance using a modified mean-variance criteria. The purpose of the study is to determine the optimal measure of reinsurance policy including type, mix and retention limit suitable for life insurers given consideration to the cost of reinsurance and the need for profitability. Data use for the research includes 425,000 life insurance policies from an unnamed large life insurer in Australia. The results of the study shows that optimal reinsurance arrangement for a life insurer depends on some factors which include number of retention limit, claim variance and predetermined risk appetite.

Meier and Outreville (2003) find that reinsurance price is one of the factors responsible for the fluctuations in the prices and profits (underwriting cycle) and hence, loss ratio of primary insurers. This is revealed in their study conducted in the property and liability insurance sector across three developed insurance markets including France, Germany and Switzerland. The research show that a decrease in the price of reinsurance will result to expansion in the underwriting capacity of primary insurers.

Yan and Hong (2015) use data gathered from the annual statement of the National Association of Insurance Commissioners (NAIC) for the years 1995-2000 to examine the presence of asymmetric information across three different reinsurance markets in the United States. The outcome of the study shows the existence of asymmetric information in the private passenger auto liability and homeowner's reinsurance markets but not in the product liability reinsurance market. In addition the study identifies the potency of retention limits as a means of cushioning the effect of asymmetric information challenges. However, long term contractual relationship has not been considered as a tool for dealing with the problem of asymmetric information. Financial performance of insurance firms has been immensely assessed by previous researchers. The outcome of most of these studies attests to the relevance of profitability to the survival of business concerns. According to Kearney (2010) the global economic crisis has brought the profitability of insurance firms in doubt. Nevertheless, Nigerian insurers are advised by Borokini as cited in Anaesoronye (2010) to take underwriting function very seriously in order to remain profitable. 
Generally, financial performance of business organisations is measured with the use of financial ratios. Abate (2012) defines financial ratio as a class of financial metrics that are used to assess a business' ability to generate earnings as compared to its expenses and other relevant costs incurred during a specific period of time. To measure the profitability of business, Al-Shami (2008) and Malik (2011) agree on a number of ratios for the measurement of financial performance. These include Return on Assets (ROA), Return on Equity (ROE) and Return on Invested Capital (ROIC). ROA is an indicator of how profitable a company is relative to its total assets. It shows how efficient the management uses its assets to generate earnings. Whereas ROE measures how much profit a company generates with shareholders' investment. ROIC is a measure used to asses a company's efficiency in allocating the capital under its control in profitable investments.

However, for the specific purpose of insurance business, Greene and Segal (2004) posit that the performance of insurance companies in financial terms is normally expressed in net premium earned, profit from underwriting activities, annual turnover, return on investment, and return on equity.

Mehari and Aemiro (2013) assess the firm specific factors that determine the performance of insurance companies in Ethiopia. They utilised data gathered from nine insurance firms in Ethiopia from 2005 - 2010. The study shows that while business size and leverage positively affect the performance of insurance firms, loss ratio has a negative relationship with insurance companies' performance. The authors therefore conclude that insurers' size, Loss ratio, tangibility and leverage are among the important determinants of insurance companies' performance in Ethiopia.

In a related research, Lee (2014) uses ordinary least square (OLS) regression model, fixed effect model (FEM) and random effect model (REM) to examine the effects of firm specific factors and macroeconomic variables on the profitability of property and liability insurance companies in Taiwan. The study engages data collected from 15 Taiwanese property and liability insurers over a period of Eleven years, from 1999 to 2009. The outcome of the study indicates that reinsurance utilisation, underwriting risk (Loss Ratio), and input cost significantly affect the profitability of insurance firms. The author therefore suggests that a reduction in the value of these three key indicators among others will translate to the profitability of insurance business in Taiwan.

Burca and Batrinca (2014) conducted a similar study in Romania with the use of econometric model. The aim of the study is to investigate the determinants of financial performance in the Romanian insurance market. The secondary data use for the study is obtained from 21 Romanian insurers from 2008 - 2012. The results of the data analysis shows that financial performance of Romanian insurance firms could be affected among other factors by growth of gross written premiums, underwriting risk (Loss Ratio), leverage, company size, and solvency margin.

A similar study performed in Kenya by Mwangi and Iraya (2014) employed multiple linear regression analysis to assess the determinants of financial performance of general insurance underwriters in Kenya. The authors obtained three years data form varying numbers of insurance firms. Data were generated from 22 insurers in 2010, 23 insurers in 2011, and 25 insurers in 2012. The result of the analysis shows that while earning asset and investment yield positively affect insurer's profitability, loss ratio and expense ratio are negatively correlated to financial performance of general insurers. However, growth of premium and size of insurer are not significant in their influence on financial performance of Kenyan general insurers. 


\section{Materials and Methods}

Secondary data is used for this study. The data is obtained from the audited annual financial reports of selected Nigerian insurance firms and therefore represent the most pragmatic view of the insurance companies. The data is generated from the financial reports published by the insurance firms, as well as on their respective websites.

The population of the study includes insurance companies in Nigeria offering non-life policies. There are about 41 of these companies operating in Nigeria at present (CIIN, 2013). Since the population of this study is a finite one, Yamane (1964) formula for determining sample size from a finite population was employed in the selection of the study's sample size at $5 \%$ level of significance.

The formula states that;

$$
\begin{aligned}
& n=\frac{N}{1+N(e)^{2}} \\
& \mathrm{n}=\text { required sample size } \\
& \mathrm{N}=\text { population } \\
& \mathrm{e}=\text { maximum margin of error at } 5 \% \\
& \text { Thus, } \\
& n=\frac{41}{1+41(0.05)^{2}} \\
& n=\frac{41}{1+0.1025} \\
& n=37.20508167 \\
& n \cong 37
\end{aligned}
$$

Although the recommended sample size is 37 companies, only sixteen (16) of these companies were selected as sample because they had complete record of the data needed for the study (2004-2013) and they represent 39\% of the total population. A percentage considered appropriate for this study base on the position of Amadi (2005). Purposive sampling technique was considered in selecting the sample. The data was generated for a ten year period that is, from 2004 to 2013 giving a 160 data set.

The data generated for this study include Ratio of Ceded Reinsurance (RCR), Ratio of Reinsurance Recoverable to Policyholders' Surplus (RRPHS), Loss Ratio (LR), and premium growth rate (PGR).

The LR and the PGR are used as proxies for dependent variables in this study. The LR shows what percentage of claim is being settled with premium received by the insurance company. It is calculated by dividing loss adjustments expenses by premiums earned. Higher loss ratios may indicate that an insurance company needs better risk management strategy. A lower rate of this ratio indicates a better financial health for an insurer. Malik (2011) used LR to study the determinants of insurers' profitability in Pakistan and found a significant negative correlation between LR and profitability. Cummins et al. (2008) and Iqbal and Rehman (2014) have also used LR as an indicator of profitability. PGR is measured as a year to year change in the new premium of insurance companies. The proxy use for this variable is sales growth (percentage change in premiums) of insurance companies. The insurers with a high premium growth rate will have low profitability due to increased underwriting risk and related provision for solvency margin (Lee, 2014; Ahmed et al., 2011).

The independent variables include the RCR and RRPHS. The RCR measures the degree to which an insurance company utilises reinsurance to fulfill its obligation to its policyholders. It is measured as ratio of gross written premiums ceded in reinsurance to total assets. It has been used in previous researches to measure the rate of reinsurance use among ceding companies. (Cole \& McCullough, 2006; Cummins, Dionne, \& Nouira, 2008; Iqbal \& Rehman, 2014b; Burca \& Batrinca, 2014). The RRPHS is an 
indication of the volume of insurance company's dependence on its reinsurers to settle claims and it indicates the rate of the insurer's exposure to the failure of the reinsurer to deliver. Its normal range is from 50\% to $150 \%$ (Smith, 2011 cited in Iqbal \& Rehman, 2014a). This ratio is used by Iqbal and Rehman (2014a) to measure the relationship between reinsurance and performance of primary insurers. The result of the study is significant.

The linear regression models developed for this study are as follows:

$P G R=\alpha_{1}+\beta_{1} R C R+\mu_{1} \ldots(1)$

$L R=\alpha_{2}+\beta_{2} R R P H S+\mu_{2} \ldots(2)$

\section{Results and Discussion}

Two hypotheses were tested in this study and results obtained were adequately interpreted, discussed and presented.

\section{Hypothesis One}

Reinsurance utilisation is not significantly related to premium growth rate of Nigerian insurers.

- Reinsurance utilisation (RCR )was derived by the formula below:

$$
\frac{\text { Reinsurance Outward }}{\text { Gross Premium }}
$$

- Premium growth rate was derived by the formula below:

$\frac{\text { Premium of Current Year - Premium of Previous Year }}{\text { Premium of Previous Year }}$

Table 1 Model Summary for Hypothesis One

\begin{tabular}{ll}
\hline $\mathrm{N}$ & 16 \\
\hline Constant (a) & -3.805 \\
\hline $\mathrm{RCR}(\mathrm{b})$ & 40.439 \\
\hline $\mathrm{R}^{2}$ & .277 \\
\hline F-Statistics & 5.365 \\
\hline p-value & .036 \\
\hline
\end{tabular}

Table 1 showed that a significant positive relationship existed between RCR and PGR because the p-value 0.036 was less than the level of significance for the study (0.05). The positive value of the co-efficient of RCR indicated that for every $1 \%$ increase in RCR, there will be a corresponding increase of $404.4 \%$ in PGR in the Nigerian insurance industry. This showed that a direct relationship existed between RCR and PGR. It therefore implied that for the insurance industry to generate profit through premium accumulation there must be constant utilisation of reinsurance.

The co-efficient of determination $\left(\mathrm{R}^{2)}\right.$ is 0.277 . This showed that only about $27.7 \%$ of the variance recorded in the dependent variable (PGR) can be explained by the independent variable (RCR) leaving about $72.3 \%$ to be explained by other factors like Expense Ratio (ER), Loss Ratio (LR), Broker and Agents' Commission, Cost of Overheads, and other Sundry Expenses. The result revealed that reinsurance utilisation is significantly related to premium growth rate of Nigerian insurers. 
This result conforms to the findings of Iqbal and Rehman (2014a) that a positive relationship exists between reinsurance utilisation and the performance of primary insurers. Iqbal and Rehman (2014b) equally found a similar result when ROA and ROE are used as proxies for profitability. The result is further justified by the findings of Lee (2014) that reinsurance utilisation is among the key determinant of insurers' profitability.

\section{Hypothesis Two}

Reinsurance dependence is negatively related to profitability (Loss Ratio) of Nigerian insurers

- Reinsurance dependence (RRPHS) was derived by the formula below:

$$
\frac{\text { Reinsurance Inward }}{\text { Assets - Liability }}
$$

- Profitability (Loss Ratio) was derived by the formula below:

$$
\frac{\text { Claims }}{\text { Gross Premium }}
$$

Table 2 Model Summary for Hypothesis Two

\begin{tabular}{ll}
\hline $\mathrm{N}$ & 16 \\
\hline Constant (a) & 0.278 \\
\hline RRPHS (b) & 0.150 \\
\hline $\mathrm{R}^{2}$ & 0.363 \\
\hline F-Statistics & 7.973 \\
\hline p-value & .014 \\
\hline
\end{tabular}

Table 2 showed that a significant positive relationship exists between reinsurance dependence and Loss Ratio, since the p-value 0.014 is less than the level of significance for the study (0.05). All other variables being kept constant, the positive value of the co-efficient of the Ratio of RRPHS showed that for every one percent increase in RRPHS, the LR increases by $15 \%$.

LR being the proportion of actual claim amount paid from the gross premium collected is an indication of the degree of profitability and the lower it is the better for the insurer. These results implied that for the Nigerian insurers to lower their cost of claims by $15 \%$, the rate of dependence on reinsurance must be reduced by $1 \%$ thereby increasing its profitability.

This result contradicts the findings of Iqbal and Rehman (2014b) which show that reinsurance dependence and exposure has no effect on insurance companies' profitability (ROA and ROE). The co-efficient of determination $\left(\mathrm{R}^{2}\right)$ is 0.363 . This indicates that about $36.3 \%$ of the variations recorded in LR are explained by RRPHS, leaving about $63.7 \%$ to be explained by other factors like loss reserving, claim forecasting, loss adjustment, litigation, and recovery opportunities through subrogation. 


\section{Conclusion and Recommendation}

The objective of this study was to establish the influence of reinsurance usage on the financial performance of Nigerian non-life insurers. Profitability is an important determinant of organisational performance. It is more important in insurance business because it measures the ability of the firm to perform its basic roles to policyholders, shareholders and other stakeholders. The outcome of the study shows that reinsurance utilisation contributes significantly to the profitability of non- life insurers in Nigeria. The results reveal that profit oriented insurers requires reinsurance to lower the underwriting and solvency risks likely to cause fluctuations in their portfolios. The results further show that for a non-life insurer to lower its loss ratio, thereby creating room for profitability, it must reduce its dependence on reinsurance. However, non-life insurance firms in Nigeria should be moderate and strategic in utilising and depending on reinsurance.

Based on the findings of this study, the researcher hereby makes the following recommendations:

i. Nigerian non-life insurers should embrace more of reinsurance facilities particularly for risks of high loss potentials. This will enhance the stability of premium growth of the portfolios.

ii. However, while considering the utilisation of reinsurance, non-life insurers should take their underwriting function very seriously in order to minimise the rate of adverse selection. This is necessary because a sound underwriting function will reduce the extent of reinsurance dependence.

iii. In addition, Insurance firms in Nigeria need to harness their claims management activities in order to minimise cost and exposure to underwriting risks.

\section{References}

Abate, G. A. (2012), Factors affecting profitability of insurance companies in Ethiopia: Panel Evidence. Unpublished M.Sc. thesis, Addis Ababa University. Available at http://www.etd.aau.edu.et

Ahmed, N., Ahmed, Z., Usman, A. (2011), Determinants of performance: A case of life insurance sector of Pakistan. International Research Journal of Finance and Economics, 61, 123-128.

Al-Shami, H. (2008), Determinants of insurance companies profitability in UAE. Unpublished Master's Thesis, University of Utara, Malaysia.

Amadi, V. L. (2005), An investigation into the role of private sector in Nigerian higher education: A case study of the University of Abuja. International Journal of Research in Education, 2(1\&2), 113-122.

Anaesoronye, M. (2010, July 1), Insurance industry premium hits N200b. Proshare. Available at http://www.proshareng.com/news/11197.html

Bangudu, O. (2013, October 24), Insurance penetration still very low, says FBN insurance. Premium Times, P. 18. Available at http://www.premiumtimesng.com

Burca, A. M., Batrinca, G. (2014), The determinants of financial performance in the Romanian insurance market. International Journal of Academic Research in Accounting, Finance and Management Sciences, 4 (1), 299-308.

Carneiro, L. A., Sherris, M. (2005), Demand for reinsurance: Evidence from Australian insurers. Working Paper. Available at http://www.business.unsw.edu.au 
Chen, Y., Hamwi, I. S. (2000), Performance analysis of U.S. property-liabilty reinsurance companies. Journal of Insurance Issues, 23, (2), 140-152. DOI: 10.1.1.199.6366.

Chen, Y., Hamwi, I. S., Hudson, T. (2001), The effect of ceded reinsurance on solvency of primary insurers. IAER, Vol. 7, No. 1, pp. 65-82. Available at http://www.link.springer.com/article/10.1007\%2FBF02296592

Chattered Insurance Institute of Nigeria, (2014), The 2013 annual report and financial statements of the council. Available at http://www.ciinnigeria.com/sites

Coleman, D. M. (2004), Reducing financial impacts on the reinsurance industry: Economic valuation of seasonal hurricane forecasts. A research done under the auspices of the Significant Opportunities in Atmospheric Research and Sciences (SOARS). Available http://www.nldr.library.ucar.edu/repository/assets/SOARS-000-000-000-069

Cole, C.R., McCullough, K.A. (2006), A Reexamination of the corporate demand for reinsurance, Journal of Risk and Insurance, 73 (1), 179-192.

Coutts, S. M., Thomas, T. R. H. (1997), Capital and risk and their relationship to reinsurance programmes. Unpublished. Available at http://www.casact.org/pubs/forum/97spforum/97spf115.pdf

Cummins, J. D., Dionne, G., Gagne, R., Nouira, A. (2008), The cost and benefits of reinsurance. A publication of the Interuniversity Research Centre on Enterprise Networks, Logistics and Transportation (CIRRELT). Available at http://www.hec.ca/iea/cahiers/2008/iea0804_rgagne

Curak, M., Utrobicic, M., Kovac, D. (2014), Firm specific characteristics and reinsurance-evidence from Croatian insurance companies. EKON MISAO PRAKSA DBK. GOD, 23(1), 29-42. Available at http://www.hrcak.srce.hr/file/182444

Dias, D., Garand, D., Swiderek, D. (2013), Towards inclusive insurance in Nigeria: An analysis of the market and regulations. A joint publication by access to insurance initiative (aii) and National Insurance Commision (NAICOM). Available at http://www.mfw4a.org

Gatumel, M., Lemoyne de Forges, S. (2013), Understanding and monitoring reinsurance counterparty risk. Literature review concerning reinsurance counterparty risk. Bulletin Francais D'Actuariat, 13(26), 121-138. Available at http://www.ressources-actuarielles.net/EXT/IA/sitebfa.nsf

Grant, E. (2012). The social and economic value of insurance. A publication of the Geneva Association. Available at http://www.genevaassociation.org

Greene, W. H., Segal, D. (2004), Profitability and efficiency in the U.S. life insurance industry. Journal of Productivity Analysis, 21, 229-247.

Iqbal, H. T., Rehman, M. U. (2014a), Reinsurance analysis with respect to its impact on the performance: Evidence from non-life insurers in Pakistan. The IEB International Journal of Finance, 8, 90-113.

Iqbal, H. T., Rehman, M. U. (2014b), Empirical analysis of reinsurance utilisation and dependence with respect to its impact on the performance of domestic non-life stock insurance companies operating in the private sector of Pakistan. International Journal of Financial Services Management, 7(2), 95-112. DOI: 10.1504/IJFSM.2014.063946.

Kearney, S. (2010), Measuring insurer profitability. Published by American Institute for Chartered Property and Casualty Underwriters. Available at http://www.aicpcu.org

KPMG. (2014), Sector report: Insurance in Africa. Available at http://www.kpmg.com/africa 
Krvavycha, Y., Sherries, M. (n. d.), Enhancing insurer value through reinsurance optimization in the presence of frictional costs. Australian Research Council. Available at http://www.businee.unsw.edu.au

Lee, C. Y. (2014), The effects of firm specific factors and macroeconomics on profitability of property-liability insurance industry in Taiwan. Asian Economic and Financial Review, 4(5), 681-691.

Malik, H. (2011), Determinants of insurance companies profitability: An analysis of insurance sector of Pakistan. Academic Research International, 1(3), 315-321.

Mehari, D., Aemiro, T. (2013), Firm specific factors that determine insurance companies' performance in Ethiopia. European Scientific Journal, 9(10), 245255.

Meier, U. B., Outreville, J. F. (2003, September), The reinsurance price and the insurance cycle. A paper presented at the $30^{\text {th }}$ seminar of the European Group of Risk and Insurance Economists (EGRIE) held in Zurich. Available at http://www.huebnergeneva.org/documents/Meier3.pdf

Mishra, M. N. (2007), Insurance principles and practice. New Delhi, India: S. Chand \& Company.

Mwangi, M., Iraya, C. (2014), Determinants of financial performance of general insurance underwritwers in Kenya. International Journal of Business and Social sciences, 5(13), 210-215.

Nigerian Insurers Association, (2011), Nigeria insurance digest 2011, Vol. 2. Available at http://www.nigerianinsurers.org

Oke, M. O. (2012), Insurance sector development and economic growth in Nigeria. African Journal of Business Management, 6(23), 7016-7023. DOI: 10.5897/AJBM11.2853.

Pan African Capital, (2013, September 19), Insurance industry: A review. A Pan African Capital Research. Available at https://www.panafricancapitalplc.com/downloadi.php

Swiss Re. (2004), Understanding reinsurance: How reinsurance create value and manage risk, Economic Research and Consulting, Swiss Reinsurance Company, Mythenquai 50/60.

Tan, K. S., Weng, C. (2012), Enhancing insurer value using reinsurance and value-atrisk criterion. The Geneva Risk and Insurance Review, 37, 109-140.

Veprauskaite, E., Sherris, M. (2012), An analysis of reinsurance optimization in life insurance. Working Paper. Available at http://www.ideas.repec.org/p/asb/wpaper/201204.html

Yan, Z., Hong, L. (2015), Testing for asymmetric information in reinsurance markets. The Geneva Papers, 40, 29-40. Available at http://www.genevaassociation.org. 